\title{
THE INFLUENCE OF DISRUPTIVE TECHNOLOGIES ON THE PREPARATION OF THE NATIONAL ECONOMY AND OF THE TERRITORY FOR DEFENSE
}

\author{
Gabriel MĂNESCU, Sebastian-Emanuel STAN \\ "Nicolae Bălcescu" Land Forces Academy, Sibiu, Romania \\ manescug@yahoo.com, sebastian.stan@armyacademy.ro
}

\begin{abstract}
The paper reviews the main factors relevant to the preparation of the economy and territory for defense as well as the main developments of military applications of disruptive technologies. The brief presentation of some of these technologies, as well as the exemplification with certain data regarding their use, come to outline the need to constantly adapt defense policies to the new trends in this field.
\end{abstract}

Keywords: disruptive technologies, defence policy, economical power, military power

\section{Introduction}

Preparing the territory to ensure the conditions necessary to defend its integrity in time of war is not a novel issue. The experience of the wars has shown that, since ancient times, there have been concerns about the material resources needed to sustain military conflicts, that they should be accumulated in time and preserved on the territory, in districts hard to reach for the enemy, near likely areas of fighting. Thus, in the feudal era, on the territory of our homeland, the necessary means for defense against invaders were kept in fortresses usually built near the country's borders, which played a special role in the great anti-Ottoman battles carried out under the leadership of the brilliant voivodes Mircea cel Bătrân, Stefan cel Mare, Mihai Viteazul and others, serving as strongholds in the fight to defend the territorial integrity and the national existence of our people and aimed to preserve weapons, ammunition, food, medicine and other means necessary for popular resistance.
As a component of national security, the preparation of the economy and territory for defense is based on the provisions of the Constitution, laws and documents on national defense planning and, last but not least, the obligations that our country has assumed through international treaties and agreements. According to Art. 2 of Law no. $477 / 2003$ on the preparation of the national economy and the territory for defense, "the preparation of the national economy and the territory for defense includes the set of measures and actions that are established and carried out in peacetime, in order to use the economic and human potential of the country, fin order to address the needs of defense and ensure the continuity of economic and social activities in case of mobilization or war"'[1].

\section{Organization and Preparation of the Territory for Defense Needs}

From the point of view of the conditions for defense, the land presents extremely varied conditions, from the natural obstacles, formed by the hydrographic network, 
orographic barriers, and forested lands and up to anthropic buildings with exclusive destination.

Natural conditions can be favorable or restrictive factors in terms of defense needs.

The organization and preparation of the territory for defense is conditioned by three essential factories, namely:

$\checkmark$ natural conditions;

$\checkmark$ the state and economic structure of a territory and the infrastructural conditions;

$\checkmark$ the evolution of fighting technique and defense policy.

It is well-known that intramountaneous territories, accessible by peaks or passes, can be more easily defended by the punctual and safe nature of the placement of roads from a possible invasion.

Defending passes has always been a priority in state defense policy. Invasion troops can be caught in ambushes, and a small number of attack forces can completely decimate the troops and the invasion technique.

Water crossings, with low banks and shallow waters, are speculated for the crossing of troops and combat equipment. That is why, as a rule, such points are strongly defended.

The forested territories are formidable shelters for manpower and fighting equipment. The organization of the defense in a forested field is favored by the possibilities of masking and sheltering the troops and fighting equipment and by the obstacle posed by the tree trunks in the way of motorized means of combat and ammunition.

The forest offers the most effective means of masking troops in advancing and retreating actions, in parallel with sheltering then in the dark of night.

Numerous examples are known from the time of the second world conflagration, when whole units in daytime marches were decimated by machine guns from lowaltitude aircraft.
From the point of view of natural conditions, the axiom remains that the heavily rugged and forested lands are easier to defend, even with reduced forces in the face of a formidable enemy.

The case of the harassment of German troops in the former Yugoslav space by J.B. Tito during World War II is one of the most eloquent examples of efficient land use.

Extreme climatic conditions are established as repulsive and hostile factors for invading troops. In parallel with the weakening of the fighting potential, the Russian winter was a reliable ally in stopping the German invasion of Moscow during World War II. American soldiers during the Vietnam War had an additional enemy in the high temperature and humidity and the unstoppable invasions of mosquitoes.

In the current situation of Romanian army's involvement on the anti-terrorist front in Afghanistan or the establishment of calm and reconstruction of Iraq, the soldiers complain mostly not about the perfidy and strength of the enemy, but more often about the unbearable heat and desert dust.

The economy of the states is dualistic, in the sense that it satisfies both civil needs par excellence, but also military needs.

During wars, a large part of the productive forces are converted to support the war (the transition from production for civilian needs to military production). In many cases, no distinction can be made between civilian and military production (e.g. food industry, textile industry, etc.).

The territorial concentration of the population, of production and their supporting infrastructures (railroads, roads, canals, channels, airports, lines for the transportation of electricity, gas and oil main avenues, water accumulations, etc.) is also a factor of remarkable territorial strength and a vulnerability factor that requires additional and diversified defense measures.

Logically, strong and modern economies allocate more substantial funds for defense. The more advanced the economy, the more 
sophisticated, diversified and effective the fighting technique. Strong economies support warring states more effectively.

Anthropic structures support the defense needs from the perspective of their destination, type and the materials from which they are built.

\section{Disruptive technologies}

The concept of disruption is not a new one, being initially characteristic of the field of electrical engineering. Harvard professor Clayton Christensen widely publicized the disruptive potential and especially that of disruptive innovation in his book The Innovator's Dillemma, published more than two decades ago, in which he describes disruption as "a new concept radically changing the foundation of competition in an industry" [2]. According to Christensen, there are two main types of technological innovations: sustainable and disruptive. Sustainable innovations are introduced to maintain a direction of past performance, preferred by most consumers. In contrast, disruptive innovations introduce a different value proposition on the market, even if the product's performance is lower, at least on short term.

As expected, the concept of disruption was quickly assimilated into almost all sectors of economic, social, political and military life.

Precisely due to the ability to manifest in various fields of activity and to the impact they entail, disruptive technologies are the subject of studies and analyzes of institutions involved in their development or which have identified direct / indirect threats.

The disruptive military technology is "an improved or completely new technology which is capable of fundamentally changing the traditional models of security and defence. The impact of these technologies will be in the necessity to redefine classic security strategies, modify military doctrines, adapt operational context or even the logic of war. Furthermore, transforming disruptive technologies into military capabilities will provoke a paradigm shift in international relations and security studies" [3].

Military specialists and politico-military analysts are united in the belief that the most important military technologies with disruptive potential are biotechnology, artificial intelligence, autonomous weapons systems, hypersonic weapons, directed energy weapons and quantum technology.

Of course, some of these, for example biotechnologies, artificial intelligence and quantum technology, can in many cases be of the dual-use type, but in this paper we aimed to highlight only their military aspects.

Biotechnology is "the field which exploits biological sciences in order to develop new technologies, some with very serious implications for national security" [4].

If the general public agrees with these and is aware of the benefits of this technology in various fields, the recent pandemic crisis generated by the SARS-Cov 2 virus, comes to overshadow and ridicule the results of decades of research. And this is due to the failure of any organization / state to assume the factors that led to its emergence, the lack of transparency and procrastination in communicating the results of investigations, the delayed or disproportionate response of state institutions and, last but not least, moral aspects / ethics.

Certainly, one of the best known areas with disruptive potential is that of artificial intelligence (AI) which can be defined as "a machine capable of imitating the cognitive functions which we conventionally associate with humans and create humanlevel knowledge" [5]. AI is used at a largescale, with military applications, such as C4ISR, cyber operations, military logistics systems, semi-autonomous and autonomous weapons systems, etc. Lately we have witnessed an unprecedented development of the phenomenon called "deep fake", based on $\mathrm{AI}$ and which has the ability to replicate in "target environments" and which has the 
role of providing a distorted picture of reality in order to undermine trust in the state authorities in charge of ensuring the defense and national security of the other areas vital for the survival of the state. Of course, this phenomenon is not new either, but the approach and the channels through which it is achieved is novel, the ability to bypass the established filters is innovative,

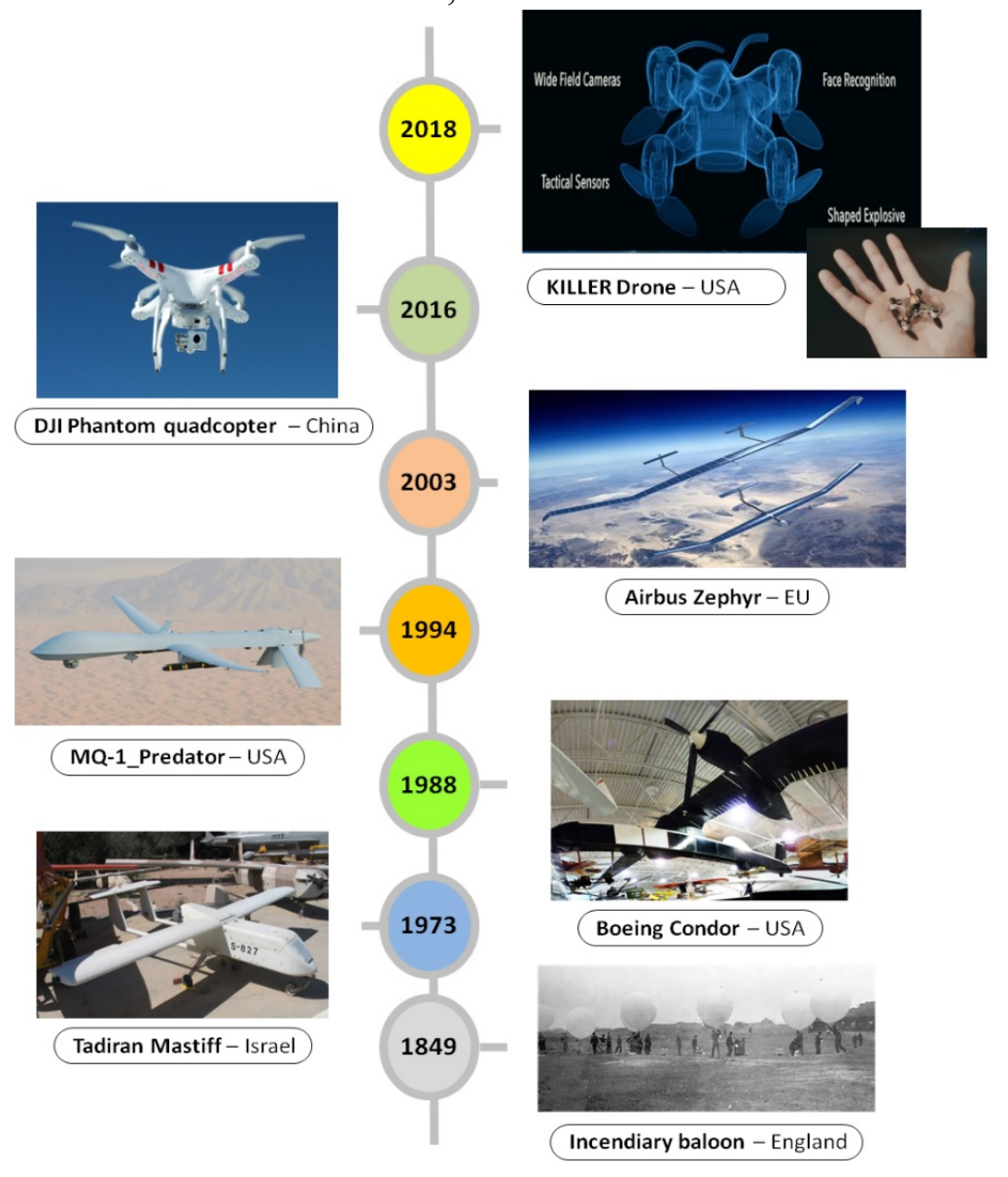

with the aim of inducing strong perceptions with potential for a credible distortion of objectivity needed in major decision moments.

A practical example, which combines the potential of AI with the development of flight systems, is that of drones, which are able to take certain decisions independently. Their evolution is shown in figure no. 1.

Figure 1: Brief history of UAV's development [6]

In support of the above, we must specify that relatively recent facts come to illustrate the capabilities of UAVs. In July 2019, several US Navy destroyers were maneuvering when, during the night, swarms of small drones harassed military ships. The event was not a singular one, as such events were reported and recorded in the ship's logs and in the following nights. What US military officials consider worrying is the fact that the presence of these UAVs has been reported at great distances from the shore, at over 160 nautical miles and, especially that there have been no reports of ships that raise suspicions about capabilities to use these systems in the area.

The autonomous lethal weapons will be " $a$ category of weapons systems which can identify, engage and destroy targets without human intervention. In the configuration of such weapons we find advanced calculations, analysis and decisions systems; sensors which can observe, identify and classify an object as hostile, as well as target guidance equipment. Their autonomy will 
allow them to operate in difficult environments for long-distance communication, command and control means" [7]. Although these systems are highly desirable by the armed forces, fortunately they have not yet been equipped with them, due to concerns about their control or more specifically whether the systems will be able to provide sufficient credible guarantees that they will comply with the rules of engagement in combat and with the laws of war that apply to the people. Some of the most current weapons systems with disruptive potential are hypersonic weapons. The fierce competition between Russia, the USA and China for supremacy in this field is well known, the first of these states having, according to some military analysts, at least two years ahead of their competitors. These systems will be able to carry explosive charges, including nuclear, with speeds up to five times the speed of sound and at distances of 2-3000 km, depending on their launch system, which gives them a high degree of protection against interception and, at the same time, an increased probability of hitting the target. "Russia has stated that its Kh-47M2 Kinzhal is a hypersonic missile which has a range of $3,000 \mathrm{~km}$, also taking into account the flight autonomy of its carrier aircraft, if it is launched from the supersonic Tu-22M3 bomber, and 2,000 km if its launched from a MiG-31K fighter jet, the configuration on which the first tests took place. Among the missile's potential targets are static or mobile objectives, either terrestrial or naval" [8].
We consider that for our investigative approach, the presentation of these capabilities of disruptive technologies are more than eloquent. As new information on the development of these technologies becomes available, we will be able to make much more detailed predictions about the configuration of possible conflicts.

\section{Conclusions}

We are witnessing unprecedented technological developments that significantly influence every aspect of life. If we refer strictly to the military aspects, the implementation of new technologies, especially the disruptive ones, we notice that they can influence / change not only the physiognomy of future conflicts, but also the current power relations. Investing in state-of-the-art technologies can bring double benefits. On the one hand, the economy of the states will benefit because all production processes / systems will benefit from the advantages offered by AI by increasing efficiency and productivity and by becoming sustainable. On the other hand, as economic power increases, so does the military power of the state. From this article it can be deduced with certainty that the first two factors that influence the defense potential of a state are canceled by the development of new weapons systems that incorporate different disruptive technologies. Of course, politico-military decision-makers will take into account the influences of new technologies in developing defense policies that best correspond to the legitimate interests of the state.

\section{References List}

[1] http://legislatie.just.ro/Public/DetaliiDocument/47873

[2] Christensen, C. The Innovator's Dillemma, Harvard Business School Press, Boston, Massachusetts, 1997Surname Initial(s). Book title. Edition - if available. Place: Publisher; Year.

[3] Iancu, I. The new dictionary of defence: disruptive technologies, Defence \& Security Monitor, 2019. Available from:https:/len.monitorulapararii.ro/the-new-dictionary-ofdefence-disruptive-technologies-1-23277

Idem 
[5] Idem

[6] Badea, D., Mănescu, G., Iancu, D., Bucoveţchi, O., Dinicu, A. "Civilian - military interferences in the management of research for the security and defense field", The 9th International Conference on Manufacturing Science and Education - MSE 2019, Sibiu, June 5 - 7, 2019, Romania, DOI: 10.1051/matecconf /20192901 MSE 2019130013001

[7] Iancu, I. Op. cit.

[8] Idem 